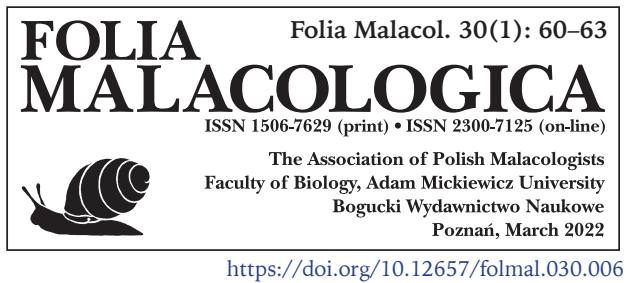

\title{
FIRST RECORD OF AQUATIC BEHAVIOUR IN AN ENDEMIC TERRESTRIAL SNAIL INDRELLA AMPULLA (BENSON, 1850) (GASTROPODA: HELICARIONOIDEA: ARIOPHANTIDAE)
}

\author{
ASHWIN LEYLAND ${ }^{1 *}$, NisHA MENZIES RAO ${ }^{2}$, ROMIT SHILPE ${ }^{3}$, ROHAN K. MENZIES ${ }^{4}$ \\ ${ }^{1}$ Independent Researcher, 553, 2nd Main Road, RBI Layout, JP Nagar 7th Phase, 560078, Bangalore, India \\ (e-mail: alleyland@gmail.com); (1) https://orcid.org/0000-0002-6072-046X \\ 2 Independent Researcher, C 106, Wilson Manor Apartments, 13th Cross, Wilson Garden, \\ Bangalore 560027, Karnataka, India; (1) https://orcid.org/0000-0002-3415-6324, \\ ${ }^{3}$ Independent Researcher, Barefoot Experiment, Vruksha Estate, Avandur Village, Bhagamandala Taluk, \\ Madikeri 571201, Karnataka, India; (1) https://orcid.org/0000-0001-6363-5749 \\ ${ }^{4}$ Independent Researcher, 107 Nidhi Apartments, 40 Netaji Road, Fraser Town, Bangalore 560005, \\ Karnataka, India; (1) https://orcid.org/0000-0002-0268-4456 \\ * corresponding author
}

ABSTRACT: Indrella ampulla (Benson) is a highly endemic species found in the Western Ghats of India which has been regarded as a terrestrial or arboreal snail since its initial description. We report the first evidence of I. ampulla exhibiting the ability to survive and move underwater. This record could change our understanding of the species and will be beneficial to conservation and research on the species which are less likely to be restricted by water barriers than previously thought.

KEY WORDS: India; Western Ghats; endemic; land snails

Terrestrial snails are among the most threatened and least studied taxonomic groups in India (MADHYASTHA et al. 2004, SEN et al. 2012). Although land snails provide important ecosystem functions such as nutrient recycling (GÄRDENFORS et al. 1995, HOTOPP 2002, MEYER et al. 2013) and are known to act as bioindicators (BERGER \& DALLINGER 1993, ALTAF et al. 2017, GHEOCA et al. 2021), there remain gaps in the basic understanding of the ecology of several species (MADHYASTHA et al. 2004). The Western Ghats of India harbor a large proportion of endemic terrestrial snail species (ARAVIND et al. 2005, RAHEEM et al. 2014, TRIPATHY \& SAJAN 2020) which are second only to amphibians in terms of endemicity (RAMAKRISHNA \& MITRA 2002, MADHYASTHA et al. 2004, RAHEEM et al. 2014). The genus Indrella, first described by GODWIN-AUSTEN (1901) is monotypic and the single species, Indrella ampulla, is easily recognised due to its large size and bright colours (BENSON 1850). Indrella was placed in a sub-genus of Ariophanta mainly due to its unique shell characteristics along with differences in its jaw, median teeth, smooth sole on the foot, and pallial margin (GODWIN-AUSTEN 1901). It is polymorphic; presenting both red and yellow morphs. I. ampulla is a Western Ghats endemic, tropical, air-breathing, terrestrial snail which is also known to exhibit a partly arboreal mode of life (MADHYASTHA et al. 2004, ARAVIND et al. 2005, MAVINKURVE et al. 2005, SEN et al. 2012). It is a highly range-restricted species found between $10^{\circ}$ and $13^{\circ} \mathrm{N}$ latitude (ARAVIND et al. 2005).

Here, we report an opportunistic observation of $I$. ampulla being able to survive in a stream. These observations were made at Avandur, Kodagu District, India $\left(12^{\circ} 23^{\prime} 41.67^{\prime \prime} \mathrm{N}, 75^{\circ} 39^{\prime} 23.62^{\prime \prime} \mathrm{E}\right)$ on 22 November 2021 (local time: 11.57 h). We have been 


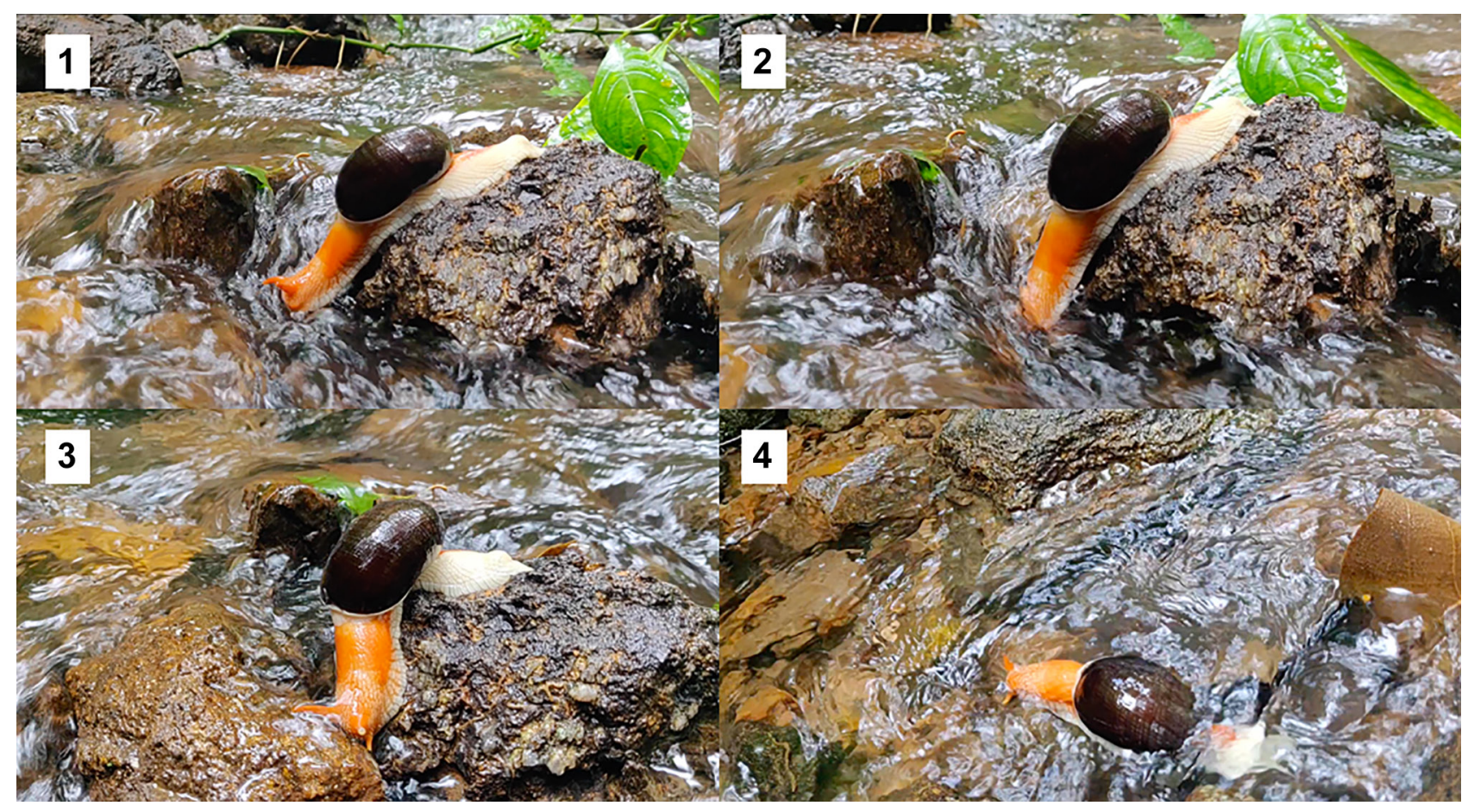

Figs 1-4. Aquatic behaviour of Indrella ampulla: 1 - initially observed on a rock in the middle of a stream, 2 - submerging its head in the water, 3 - attempting to move on the rocks, 4 - entering the stream with its body submerged underwater and crossing to the other bank. Photos: ASHWIN LEYLAND

sporadically observing I. ampulla for over 3 years with more focused efforts since July 2021 and these are the first observations of an individual underwater. The snail was not handled or manipulated in any way. AL recorded all observations on a OnePlus 6T McLaren phone.

While on a break beside a stream, we observed an adult $I$. ampulla on a mostly submerged rock in the middle of the current (Fig. 1). Initially, the snail inserted its head and tentacles into the water for several seconds while its foot was firmly fixed on a rock (Fig. 2; Supplemental Video 1). The snail was then observed attempting to cross from one rock to the next with water flowing in between (Fig. 3; Supplemental Video 2). Finally, the snail left the rock, entered the stream with its body completely submerged underwater, and only the top of its shell above the surface while moving on the substrate (Fig. 4; Supplemental Video 3 ). The individual was then able to cross the stream while submerged and climb onto another rock close to the stream's edge. The pneumostome remained closed for the duration the snail spent underwater and it occasionally broke the surface with a single upper tentacle. The entire observation lasted approximately 30 minutes after which the snail climbed onto a branch at the stream edge and disappeared into the undergrowth. Due to the arboreal nature of the snail, it is possible that this individual fell into the water from the trees above since we did not witness it enter the water from the stream bank to reach the initial observation point; however, it was able to survive in the gushing stream, remain submerged for an extended period of time, move on the stream-bed, and re-emerge on the other side of the stream. Based on the cracks observed on the shell, it is equally possible that the snail attempted to cross further upstream and was washed down to the point where the flow had slowed down and was then able to move up onto the rock.

This novel observation could have several implications and lead to interesting ecological questions concerning this species. Given the historical and current assumption that I. ampulla is terrestrial and arboreal, our record suggests that these snails are capable of crossing water provided there is a substrate to move on and therefore are not restricted to certain sites by streams, thereby changing our understanding of the range and distribution of the species. Moreover, our observations suggest that I. ampulla can survive in water for about 30 minutes with its pneumostome submerged for the duration and only its upper tentacles occasionally breaking the surface. It is possible that I. ampulla has exhibited a form of passive dispersal by water which has been previously reported in helicid snails such as Arianta arbustorum (L.) (KÜNKEL 1916, BAUR 1986). Aquatic behaviour is not restricted to terrestrial snails and has been reported in slugs as well (HARO et al. 2004). The rarity of this sighting also suggests that this is perhaps not a preferred behaviour of I. ampulla and the low water levels during winter could have contributed to these observations by allowing the individual to cross. Of 
the 103 observations on INATURALIST (2022) and 27 photographs on the Indian Biodiversity Portal (VATTAKAVEN et al. 2016), retrieved on 9 December 2021, none are of a submerged I. ampulla. With our limited understanding of this species, new aspects of behaviour are crucial to accurate studies and conservation. Further research focused on I. ampulla is required to understand its relationship with the habitat and the conditions associated with its behaviour which allows it to survive.

\section{REFERENCES}

AltAF J., QURESHI N. A., SidDIQUI M. J. I. 2017. Terrestrial snails as bioindicators of environmental degradation. Journal of Biodiversity and Environmental Science 10: 253-264.

Aravind N. A., Rajashekhar K. P., Madhyastha N. A 2005. Species diversity, endemism and distribution of land snails of the Western Ghats, India. Records of the Western Australian Museum Supplement 68: 31-38. https://doi.org/10.18195/issn.0313-122x.68.2005.031-038

BAUR B. 1986. Patterns of dispersion, density and dispersal in alpine populations of the land snail Arianta arbustorum (L.) (Helicidae). Ecography 9: 117-125. https://doi.org/10.1111/j.1600-0587.1986.tb01200.x

BENSON W. H. 1850. XXI. Characters of several new East Indian and South African Helices, with remarks on some other species of the Genus occurring at the Cape of Good Hope. Annals and Magazine of Natural History 5(27): 213-217. https://doi.org/10.1080/03745486009494916

Berger B., DALlinger R. 1993. Terrestrial snails as quantitative indicators of environmental metal pollution. Environmental Monitoring and Assessment 25: 65-84. https://doi.org/10.1007/BF00549793

GÄRDENFORS U., WALDÉN H. W., WÄREBORN I. 1995. Effects of soil acidification on forest land snails. Ecological Bulletins 44: 259-270. https://www.jstor.org/stable/20113168

GHEOCA V., BENEDEK A. M., SCHNEIDER E. 2021. Exploring land snails' response to habitat characteristics and their potential as bioindicators of riparian forest quality. Ecological Indicators 132: 108289. https://doi.org/10.1016/j.ecolind.2021.108289

GodwIN-Austen H. H. 1901. On the anatomy of the Helix ampulla of Benson, and its generic position in the Ariophantinae. Journal of Molluscan Studies 4: 187190. https://doi.org/10.1093/oxfordjournals.mollus.a065812

HARO R. J., GILliS R., COOPER S. T. 2004. First report of a terrestrial slug (Arion fasciatus) living in an aquatic habitat. Malacologia 45: 451-452.

НоторР K. P. 2002. Land snails and soil calcium in central Appalachian Mountain forest. Southeastern Naturalist 1: 27-44.

https://doi.org/10.1656/1528-7092(2002)001[0027: LSASCI]2.0.CO;2

\section{ACKNOWLEDGEMENTS}

We would like to thank JABEEN MENZIES and RUSSELL MENZIES for supporting this project. We are grateful to LIEW THOR SENG and two anonymous reviewers for their valuable comments which helped improve this note.

INATURALIST 2022. iNaturalist web page. Available from https://www.inaturalist.org (accessed 9 December 2021).

KÜNKEL K. 1916. Die Biologie der Lungenschnecken. Carl Winter, Heidelberg.

MADHYASTHA N. A., MAVINKURUVE R. G., SHANBHAG S. P. 2004. Land snails of Western Ghats. ENVIS Bulletin: Wildlife and Protected Areas, Conservation of Rainforest in India 4: 143-151.

MaVinkuRVE G., Shanbhag P., MAdHyastha N. A. 2005. Description of few land Molluscs from Kodagu district of Karnataka, India. Records of the Zoological Survey of India 105: 117-125.

MEYer III W. M., OSTERTAG R., COWIE R. H. 2013. Influence of terrestrial molluscs on litter decomposition and nutrient release in a Hawaiian rain forest. Biotropica 45: 719-727. https://doi.org/10.1111/btp.12057

Raheem D. C., Taylor H., Ablett J., Preece R. C., ARAVIND N. A., NAGGS F. 2014. A systematic revision of the land snails of the Western Ghats of India. Tropical Natural History 4: 1-294.

https://li01.tci-thaijo.org/index.php/tnh/article/ view/103091

RAMAKRISHNA, MiTRA S. C. 2002. Endemic land molluscs of India. (Ed. Director, ZSI). Records of the Zoological Survey of India, Occasional Paper No. 196: 1-65.

SEN S., RAVIKANTH G., ARAVIND N. A. 2012. Land snails (Mollusca: Gastropoda) of India: status, threats and conservation strategies. Journal of Threatened Taxa 4: 3029-3037. https://doi.org/10.11609/JoTT.o2722.3029-37

SEN S., SHIVPRAKASH K. N., ARAVIND N. A., RAVIKANTH G., DAYANANDAN S. 2016. Ecological niche modeling for conservation planning of an endemic snail in the verge of becoming a pest in cardamom plantations in the Western Ghats biodiversity hotspot. Ecology and Evolution 6: 6510-6523. https://doi.org/10.1002/ece3.2368

TRIPATHY B., SAJAN S. 2020. Mollusca: Gastropoda. In: CHANDRA K., RAghunAthan C., SUREShan P. M., SUBRAMANIAN K. A., RIZVI A. N. (eds). Faunal diversity of biogeographic zones of India: Western Ghats. Zoological Survey of India, Kolkata, pp. 613-626. 
VAtTAkaven T., George R., Balasubramanian D., Received: December 30th, 2021 RÉJOU-MÉCHAIN M., MuthuSANKAR G., RAMESH B., Revised: February 19th, 2022 PRABHAKAR R. 2016. India Biodiversity Portal: An inte- Accepted: February 21st, 2022 grated, interactive and participatory biodiversity informatics platform. Biodiversity Data Journal 4: e10279. Published on-line: March 5th, 2022 https://doi.org/10.3897/BDJ.4.e10279

\section{SUPPLEMENTAL VIDEOS}

Indrella ampulla on a rock in the middle of the stream observed submerging its head and tentacles into the water (Supplemental Video 1, corresponds to Fig. 2).

Indrella ampulla subsequently seen trying to move from one rock to the next rock while still in the stream (Supplemental Video 2, corresponds to Fig. 3).

The body of Indrella ampulla submerged in the stream with its tentacles underwater while it crossed to the other stream bank (Supplemental Video 3, corresponds to Fig. 4). 